\title{
Audit quality in ASEAN region: some efforts and comparisons
}

\author{
Irma Tyasari ${ }^{1, *}$, Nor Zalina Mohamad Yusof ${ }^{1 \dagger}$, and Ku Maisurah Ku Bahador ${ }^{1}$ \\ ${ }^{1}$ Tunku Puteri Intan Safinaz School of Accountancy, Universiti Utara Malaysia, 06010 Sintok, Kedah, \\ Malaysia
}

\begin{abstract}
This paper discusses how Asian economies are responding to the increased global attention on audit quality (AQ) issues. It shows some of the efforts taken by the countries collectively as a region; as well as individual countries' measures. The data is obtained from various reports available in public domain including the information available on various relevant websites. The discussion shows how Asian countries are working through an informal organization they established, called the ASEAN Audit Regulators Group (AARG) in enhancing AQ. Comparison among five ASEAN countries shows variations in term of how much each country has progressed with respect to their efforts in straightening AQ. Some countries are more advanced than the other. This paper contributes to the literature on audit quality by providing insights into how ASEAN as a region responded to the global demand on improving AQ and the gaps in auditing literature on comparative progress of these nations.
\end{abstract}

\section{Introduction}

In the year 2002, the US's biggest energy firm, Enron, collapsed; bringing together its auditor, Arthur Andersen \& Co. The accounting landscape changed with the establishment of the Sarbanes Oxley Act (SOX) 2002, which has global impact to the profession. Since then, audit quality (AQ) has become a major focus of all relevant parties, be it accounting regulators, practitioners, accounting professional bodies, and accounting academics.

More than a decade later, despite various efforts and measures taken by these parties to enhance AQ, it is still very much a concern. In 2015, for example, a global survey by the International Forum of Independent Audit Regulators (IFIAR) on its 29 members from different jurisdictions finds that audit still unable to provide the level of assurance expected of it by the users of financial statements. More alarmingly, the concern is centered on audit procedures deficiencies with the most deficiencies are also those most fundamental to the quality of financial statements [1]. In the same year, the UK Financial Reporting Council (FRC) also published its report on AQ that indicates that although AQ is improving, but there is still room for improvements.

As concerns mounted, accounting bodies continue to work towards enhancing the AQ. In January 2016, the US Center for Audit Quality (CAQ), which is affiliated with the American Institute of CPA (AICPA), has published their insights learned from a series of roundtable discussions with various stakeholders to gather their feedback on a potential set of audit quality indicators. This is following their release of the "CAQ Approach to Audit 
Quality Indicators" (AQI) in 2014 [2]. The AICPA itself has published the "AICPA's Enhancing Audit Quality (EAQ)" initiative in 2014 to address AQ challenges on a holistic, ongoing basis, with the goal of improving audit performance. A year later, they published the "6-Point Plan to Improve AQ" that describes extensive ongoing and new efforts to improve AQ. These initiatives show that AQ is still receiving a significant focus at the global level [2].

Being part of the global economy, ASEAN countries have also been focusing their attention on the issues of AQ. Efforts have been taken although some claimed that the movements could be for legitimacy as much as for efficiency reason [3]. Some argues that such initiatives are due to requirement of international organizations such as the World Bank and the International Monetary Fund (IMF) [4]. Others suggest that the attention is due to practical problems experienced in each country $\left([4]^{1},[5]^{2}\right)$. Notwithstanding these, efforts are being taken by these emerging economies, not only at individual country level, but also they are working together collectively at regional level.

In 2011, Malaysia, Singapore, and Thailand, have taken their step to promote better $\mathrm{AQ}$ in the region. The Accounting and Corporate Reporting (ACRA) of Singapore, the Securities and Exchange Commission (SEC) of Thailand, and Malaysia's Audit Oversight Board (AOB) - all of which are members of IFIAR, came together and founded the ASEAN Audit Regulators Group (AARG). This informal organization aims to promote AQ in the region through enhanced collaboration between audit regulators. Its "roles extend to elevating audit oversight and quality in the region and being a channel for knowledge sharing and promoting ASEAN capital markets linkage together with cross-bordering offering under equivalent standards of high quality financial reporting" [6].

In 2015, the region has integrated itself economically into the ASEAN Economic Community or AEC. This is a result of the first AEC Blueprint, signed in November 2007 that served as a master plan to chart its establishment in December 2015. This makes ASEAN a huge global market. In 2014, AEC was collectively the third largest economy in Asia and the seventh largest in the world [7]. With the AEC, it is not only that the region needs strong AQ in penetrating the global economy, but each country inside the AEC has to have comparable AQ for being integrated as a single market and production base. However, given these initiatives, comparative studies in ASEAN on this AQ issue are still lacking.

This paper, therefore, aims to discuss what recent initiatives are being taken by ASEAN in relation to AQ. It is hoped that this will provide insight into how much the region has progressed in terms of improving its AQ as well as giving ideas into whether these developing economies are comparable among themselves, and with the developed nations in this regard. The focus is not only on collective efforts in the region, but also on individual country's efforts. This is important particularly with the formation of AEC. However, although the AEC is made up of ten nations in South East Asia, the focus of this study is only on five of its economies, namely Singapore, Thailand, Philippine, Malaysia, and Indonesia. The limited focus is due to availability of data as well as the relative importance of the countries in playing their roles in AEC.

Data is obtained from various reports available in public domain including the information available on various relevant websites. This includes annual reports of accounting regulatory bodies, newspaper articles, and press releases. In this paper, AQ is defined as "the market-assessed joint probability that a given auditor will both (a) discover a breach in the client's accounting system, and (b) report the breach" [8].

\footnotetext{
* Corresponding author: Irmatyasari26@gmail.com

${ }^{1}$ Pusat Pembinaan Profesi Keuangan (Accountant Services Development Centre under the Minister of Finance Department of Indonesia);

${ }^{2}$ Indonesian Institute of Public Accountants
} 
This paper is organized as follow: the next section discusses the efforts taken by ASEAN economies collectively. This is followed by a section that compares the initiatives taken by five of the countries under the AEC as stated above. Comparisons are made in the areas related to their regulations, the number of accountants, the training requirement, and professional bodies' collaboration with academic institutions. Other countries under the AARG are not included due to inability to obtain sufficient data. This paper ends with some concluding remarks.

\section{Collective efforts by ASEAN}

In ASEAN, there are two regional accountancy organizations, which are, the ASEAN Federation of Accountants (AFA) - established in 1977; and the Confederation of Asian and Pacific Accountants (CAPA), established in 1976. However, the discussion on regional efforts will focus more on the efforts done by AARG. This is because, AFA is not formally recognized and acknowledged by IFAC; while for CAPA, although it is recognized by IFAC, only two ASEAN countries are members of this organization [9]. Furthermore, although AARG is made up of only three ASEAN countries, but the involvement in its efforts come from many other countries and relevant parties including audit firms. In terms of membership, while AARG is consists of accounting regulatory bodies of members' country, AFA and CAPA are consisting of the country members' accounting professional bodies. It is also interesting to focus on AARG as it appears very active since its establishment in 2011, and is affiliated to a world organization, IFIAR.

IFIAR is a global body, established in 2006 by 17 countries; now its membership has reached to 51. The body consists of independent audit regulators from various jurisdictions around the world. In promoting AQ, IFIAR has provided a platform for regulators to share knowledge and practical experience gained from their independent audit regulatory activity. As an affiliation to IFIAR, AARG also has adopted similar approaches to promote AQ, which is through discourse. There are initiatives taken by AARG in relation to enhancement of AQ in the region. The annual meeting and Audit Inspection Workshops mirror those conducted by IFIAR. Working with the World Bank on collaborative efforts to further raising the standard of AQ in ASEAN, and roundtable discussion with other related agencies and Big Four Audit Firms for specific issues concerning audit are other initiatives [1]. The collaboration of AARG has created impact on AQ in the region. The evidence of AARG's contribution is stated in AOB's Annual Report of 2013 [6].

\section{Efforts at national level}

Discussion and comparisons on efforts at individual country level is focused on four areas, namely, their regulations, the number of accountants, the training requirement, and professional bodies' collaboration with academic institutions [9].

\subsection{Enhancements to the statutory and institutional framework}

The enhancement to statutory and institutional framework means that the way the regulatory bodies or agencies improve monitoring and enforcement of accounting and auditing mechanism, and how they put place the basic of effective regulations. There should be a consistency between the legal frameworks with the adoption of international standards to create effectiveness. The general impact of the changes caused by the new 
regulations or new standards is expected to modernize the regulation itself to reflect the adjusted proficient environment that has developed because of emerging worldwide economy [10].

This condition also gave impact to ASEAN countries. There is a progressive move away from self-regulation of auditing by the profession towards an independent regulation within a statutory framework [11]. The regulators have made several efforts in enhancing their statutory and institutional framework concerning AQ due to the changes. One of such effort as evidence is that a country is committed in AQ is by adopting international standards ([3], [12]). However the successful implementation of international standards is very dependent on local conditions. The process of adopting standards and adapting changes has been a challenge among countries regarding the issues of capacities [13].

There is a great deal of variations among ASEAN countries relation their progress and the enhancement of statutory and institutional framework. The main task of regulator is to prepare the formulation of policies, guidance, development and supervision of accountants. In addition, they are also the administrator of registration and licensing of accountants, and imposition of administrative sanctions against the professions. Each regulator has a quality review program which is mandatory because it is one of the requirements of IFAC for its member to demonstrate commitment in quality ([4], [9], [11], [24]). The five countries have established professional associations which have various functions whether as standard setter, supervisor of enforcing compliance, regulatory body, Continuous Professional Development (CPD) and accountants' certification examinations provider.

\subsection{Number of professional accountants}

As explained in previous paragraph, ASEAN is a large potential market, and strengthening the accountancy profession will ensure adequate number of accountants to meet of its growing economy. Various programs are being offered by the regulators of each country to attract, improve and promote the accountancy profession. Collaborative arrangements between universities and professional associations may support this effort. Besides increasing the number of professional accountants, improving the capacity building of both sides may fill the gap between the interests, and the market's expectation ([15], [16]). An example of such effort is having harmonized international standards (curricula), and giving opportunities for graduates to obtain the appropriate practical experience ([17], [18], [19]).

Indonesia has given a serious consideration regarding the issue above. The country's regulators have created a program to scale up the number of Indonesian accountants because comparing to other ASEAN countries; it only contributes less than $15 \%$ of the total accountants in ASEAN in 2015 [9]. Based on the data of AFA, Indonesia has greatly increased the number of its accountants in 2015. This is due to the two programs conducted by IAPI and IAI ([9], [20], [23]). These two programs are similar and comparable to the ones which being conducted in Malaysia, Thailand and Singapore [9]. The table below shows the numbers of accountant's in 5 (five) number ASEAN countries.

Table 1: Numbers of accountant by Year (from 2010- 2015)

\begin{tabular}{lllllll}
\hline Country & $\mathbf{2 0 1 0}$ & $\mathbf{2 0 1 1}$ & $\mathbf{2 0 1 2}$ & $\mathbf{2 0 1 3}$ & $\mathbf{2 0 1 4}$ & $\mathbf{2 0 1 5}$ \\
\hline Thailand & 51,737 & 61,331 & 54,319 & 57,244 & 63,691 & 68,777 \\
Singapore & 23,626 & 24,774 & 25,726 & 27,397 & 28,530 & 24,774 \\
Philippine & 21,599 & 21,939 & 22,567 & 22,072 & 21,586 & 19,380 \\
Malaysia & 27,292 & 28,148 & 29,179 & 30,503 & 31,454 & 32,511 \\
Indonesia & 8,600 & 9,624 & 12,548 & 17,649 & 18,507 & 26,782 \\
\hline
\end{tabular}

(Source: [9]) 


\subsection{Continuous training programs}

Another effort which the regulators have committed to meet the challenges of the changes in the auditing profession and may increase the AQ is by having CPD program [22]. The objective is to encourage the culture of continuous learning among professionals [21]. Through this program government can socialize and introduce the updated standards and regulations to the accounting and auditing practitioners. The comparison of CPD requirement for accountants in five ASEAN countries shows that the range of CPD hours is between 18-40 hours per year. This is clearly that a certified accountant must meet the minimum CPD requirements in order to maintain his or her professional status. Each country has its own minimum hour requirement to be fulfilled that has been laid out by its respective professional associations ([9], [24]).

\begin{tabular}{cccccc}
\hline Country & Singapore & Thailand & Philippine & Malaysia & Indonesia \\
\hline $\begin{array}{c}\text { CPD } \\
\text { Hours/Year }\end{array}$ & 30 & 18 & 20 & 30 & 40 \\
\hline
\end{tabular}

(Source: [9], [24], [25])

\subsection{Collaboration with higher educational providers}

One of the impacts of the global changes is the adoption of new standards which has led professional associations and regulators to collaborate with leading universities to strengthen the accountancy profession. The parties involved are committed to promote and develop the profession ([20], [23]). They play a significant role in the formulation of the curriculum for the accounting degree programs. Among the endeavours involved are providing trainings and workshops to introduce new standards to educators; offering internationally comparable accountancy education to match the contemporary requirements of the profession; revising the curricula and teaching methods based on the new principles of the latest standards, and opening a career path for accounting graduates. There are events of such collaborative programs among the parties involved according to each country, such as ISCA with ICAEW, Ministry of Commerce with FAP, the Commission on Higher Education (CHED) with PICPA, MIA has International Engagement for sharing best practice and lesson learnt and IAI with $\operatorname{ICAEW}([9],[23])$.

\section{Conclusion}

The discussion in this paper shows how, at regional level, ASEAN is closely following the efforts taken at global level by the IFIAR in improving the audit quality. The Initiatives at this level is more of discursive in nature. The various efforts taken are consistent with its intention to penetrate the global economy through AEC. However at the individual country level, it could be seen that some countries are more ahead then others. More collaborative efforts will be undertaken by the relevant parties to reduce the differing capacity level of these countries.

\section{References}

[1] International Forum of Independent Audit Regulator (IFIAR). Retrieved online from https://www.ifiar.org/About-Us.aspx (2015) 
[2] Center for Audit Quality (CAQ). Retrieved online from http://www.thecaq.org/reportsand publications/audit-quality-indicators-journey-and-path-ahead (2016)

[3] P. L. Joshi, W. G. Bremser \& J. Al-Ajmi. Perceptions of accounting professionals in the adoption and implementation of a single set of global accounting standards: Evidence from Bahrain. AA, 24(1), 41-48 (2008)

[4] Pusat Pembinaan Profesi Keuangan (PPPK). Retrieved online from http://pppk.kemenkeu.go.id/News/20 (2015)

[5] Institut Akuntan Publik Indonesia (IAPI). Retrieved online from http://iapi.or.id/detail/64-Reviu-Mutu (2015)

[6] Audit Oversight Board (AOB). Annual Report 2013. Retrieved online from https://www.sc.com.my/general_section/audit-oversight-board/ (2013)

[7] ASEAN Economic Community (AEC). Retrieved online from http://asean.org/aseaneconomic-community/ (2015)

[8] L. E. DeAngelo. Auditor size and audit quality. JAE, 3(3), 183-199 (1981)

[9] ASEAN Federation of Accountants (AFA). Retrieved online from http://www.aseanaccountants.org/home (2015)

[10] C. Hayes. The Ramsay report and the regulation of auditor independence in Australia. AAR, 12(2), 3 (2002)

[11] ASEAN Federation of Accountants (AFA). Retrieved online from http://www.aseanaccountants.org/home (2014)

[12] D. Wang, \& J. Zhou. The impact of PCAOB Auditing Standard No. 5 on audit fees and audit quality. AH, 26(3), 493-511 (2012)

[13] M. Tokar. Convergence and the Implementation of a Single Set of Global Standards: The Real-life Challenge. AE, 2(1), 47-68 (2005)

[14] Accounting and Corporate Regulatory Authority (ACRA). Retrieved online from https://www.acra.gov.sg/Legislation/Accountants_Act/ (2016)

[15] Nazri Fadzly, Mohamed, and Zauwiyah Ahmad. Audit expectation gap: The case of Malaysia. MAJ. 19.7 (2004)

[16] T.H. Lee, R. Mohamad, N. Z. M. Yusof \& M. Ojo. Practical training and the audit expectations gap: The case of accounting undergraduates of Universiti Utara Malaysia. JFRA (Emerald Publication) Fourth coming (2007)

[17] J. M. Mula. Can competency skills for accounting students be internationally harmonised? An Indonesia application. AEG (SIG5) Symposium, AFAANZ (2007)

[18] M. Saito, K. Hiramatsu, \& S. Mayangsari. Accounting Education for the Implementation of IFRS in Indonesia. IRB, 12, 1-21 (2012)

[19] K.I. Dandago, \& N. A. B. Shaari. Effects of focus of accounting research on the quality of accounting education in Malaysian Universities. AEFR, 3(10), 1371 (2013)

[20] Ikatan Akuntan Indonesia (IAI). etrieved online from http://iaiglobal.or.id/v03/CA/home (2015)

[21] P. De Lange, B. Jackling, \& I. G. Basioudis, A framework of best practice of continuing professional development for the accounting profession. AE, 22(5), 494497 (2013)

[22] Y.S. Cheng, Y.P. Liu, \& C.Y. Chien. The association between auditor quality and human capital. MAJ, 24(6), 523-541 (2009)

[23] Institut Akuntan Publik Indonesia (IAPI). Retrieved online from http://iapi.or.id/assets/collections/doc/prp.pdf (2015)

[24] Institut Akuntan Publik Indonesia (IAPI). Retrieved online from http://iapi.or.id/peraturan/ (2015)

[25] Pusat Pembinaan Profesi Keuangan (PPPK). Retrieved online from http://pppk.kemenkeu.go.id/News/20http://pppk.kemenkeu.go.id/News/Details/29 (2015) 